\title{
ARABISASI PEMERINTAHAN ISLAM PADA MASA KHALIFAH ABDUL MALIK BIN MARWAN
}

\author{
Surma Hayani*, Nurhasanah Bakhtiar \\ Program Magister Pendidikan Guru Madrasah Ibtidaiyah UIN Sultan Syarif Kasim, Riau, Indonesia
}

\begin{abstract}
The Umayyah goverment reign was led by the Calioh Abdul Malik bin Marwan in the year $23 \mathrm{H}-86 \mathrm{H}$, namely to advance and develop the goverment to spread Islamic law. But at the time Abdul Malik bin Marwan experienced Arab difficulties because there were thise who opposed him in dominating the Arab state, named Hajjai bin Yusuf ats Tsaqafi, the were fighting for the power of the state and nation but the one who succeeded in this struggle was Abdul Malik bin Marwan. Therefore the purpose of analyzing the Islamic government developed by the Caliph from this Abdul Malik bin Marwan as well as important event and policies in the Umayyah Dynasty leadership Furthermore, this type of research is the type of library research using qualitative methods with a historical approach. The results of this study are Caliph Abdul Malik bin Marwan made turning Arabic into an official substitute for the country's currency, renewal of the taxation area, the development of a craft post system and other.
\end{abstract}

Keywords: Islam government, progress, development, Abdul Malik bin Marwan.

\section{Abstrak}

Pemerintahan Dinasti Umayyah yang dipimpin oleh Khalifah Abdul Malik pada tahun $23 \mathrm{H}-86 \mathrm{H}$, yaitu memajukan dan mengembangkan pemerintahan Arab dengan menyebarkan syariat-syariat Islam. Tetapi pada masa itu juga Abdul Malik bin Marwan mengalami kesulitan karena ada yang menentangnya dalam menguasai negara Arab, yang bernama Hajjaj bin Yusuf ats-Tsaqafi, mereka memperebutkan kekuasaan negara dan bangsa, tetapi yang berhasil dalam perebutan ini ialah Abdul Malik bin Marwan. Oleh sebab itu tujuan dari tulisan ini adalah untuk menganalisis pemerintahan Islam yang dikembangkan oleh khalifah Abdul Malik bin Marwan serta peristiwa penting dan kebijakan dalam kepemimpinan Dinasti Umayyah. Selanjutnya jenis penelitian ini adalah jenis penelitian kepustakaan (library research), dengan menggunakan metode kualitatif dengan pendekatan histories. Hasil dari penelitian ini adalah khalifah Abdul Malik bin Marwan menjadikan menjadikan bahasa Arab menjadi bahasa resmi negara, mengganti mata uang, pembaharuan ragam tulisan bahasa Arab, pembaharuan bidang perpajakan, pengembangan sistem pos, kerajinan dan lain-lain.

Kata Kunci: pemerintahan Islam, kemajuan, perkembangan, Abdul Malik bin Marwan.

\section{PENDAHULUAN}

Munculnya Agama Islam merupakan awalan dari Pemerintahan Arab. Dari segi sejarah, Islam muncul sejak turunnya wahyu kepada Rasulullah SAW. Rasul membawa bangsa Arab yang awalnya bangsa tersebut bodoh dan diabaikan oleh bangsa lain. Kemudian, dengan masuknya Islam maka bangsa tersebut maju dan berkembang sampai sekarang ini. Agama Islam yang disebar Rasulullah dapat menggerakkan, memajukan, mengembangkan kebudayaan dan peradaban dalam sejarah manusia. Bahkan, kemajuan dunia Barat mulanya bersumber dari peradaban Islam yang mana bersumber dari kebudayaan Islam yang masuk ke Eropa melalui Spanyol. Karena yang menjadi pokok kekuatan dan sebab timbulnya kebudayaan adalah agama Islam, kebudayaan yang muncul itu dinamakan peradaban Islam yang awal berkembangnya pada pemerintahan Arab (Rianawati, 2010, p. 9).

Pada saat ini, apabila peradaban Islam tidak dapat dilestarikan atau dijaga oleh bangsa Arab pada waktu itu, maka agama Islam akan mengalami penurunan dan *Correspondance Author: surmahayani24@gmail.com Article History | Submitted: December 22, 2019 | Accepted: December 25, 2019 | Published: January 17, 2020 How to Cite (APA $6^{\text {th }}$ Edition style):

Hayani, S., N. Bakhtiar. (2020). Arabisasi Pemerintahan Islam pada Masa Khalifah Abdul Malik bin Marwan. 
kepunahan. Pada pemerintahan Dinasti Umayyah pada masa itu memberikan babak baru untuk kemajuan pemerintahan Arab yang dapat dilihat dengan pemberianpemberian dalam memperluaskan wilayah, kemajuan pendidikan, kebudayaan dan lain-lainnya (Kuswanjono, 2016, p. 292).

Mengembangkan dan memajukan Pemerintahan Arab, diklasifikasikan pada periode klasik (650-1250 M), periode pertengahan (1250-180o M) dan periode modern (180o-sekarang). Periode klasik, pada masa itu pemerintahan Arab terjadi pada beberapa khalifah yang sangat menonjol yaitu Khalifah Abdul Malik bin Marwan. Peradaban Islam yang berkembang pada masanya ialah menjadikan bahasa Arab menjadi bahasa resmi negara, mengganti mata uang, pembaharuan ragam tulisan bahasa Arab, pembaharuan dalam bidang perpajakan, pengembangan sistem pos, membentuk Mahkamah Agung, membangun masjid, kerajinan dan lain-lainnya (Nizar, 2013, p. 59-6o). Semua itu dilakukan oleh Abdul Malik bin Marwan dengan kerja kerasnya untuk kemajuan dan perkembangan bangsa dan Negara Arab (M. Kholison, 2015, p. 5).

Dari penelitian sebelumnya, dijelaskan bahwa pada masa pemerintahan Bani Umayyah dapat dilihat dari tiga fase yaitu; fase terbentuk, kejayaan dan kemunduran diantaranya pada masa khalifah Abdul Malik yang merupakan orang kedua yang terbesar dalam deretan pada khalifah Bani Umayyah. Pada masa pemerintahannya ia mampu mengembalikan sepenuhnya dalam mengintegrasikan wilayah dan berwibawa dalam kekuasaan Bani Umayyah yang ditunduknya dari gerakan sepatis Abdullah bin Zubair di Hijjaz, yang memberontak yaitu kaum Syi'ah dan Khawarij, aksi teror alMukhtar bin Ubaid As-Saqafi di Kufah, pemberontakan Mus'ab bin Zubair di Irak, serta Romawi yang menguncang sendi-sendi pemerintahan Umayyah (Taufik Rachman, 2018, p. 91).

Penelitian yang kedua, menjelaskan bahwa Abdul Malik dengan Walid mendirikan bangunan yang berupa kubah batu, Masjid Damaskus, memperluas masjid al-Haram dan masjid Nabawi yang berada di Yerussalem. Pada saat sekarang ini bangunan itu didirikan menjadikan salah satu monumen Islam terbesar di dunia. Pada masjid Kubah Batu, gaya bangunan itu dicampurkan dari kebudayaan Bizantium dan Persia. Pada masa Walid bin Abdul Malik (putra Abdul Malik bin Marwan) dibangun masjid agung yang terkenal yaitu Masjid Damaskus. Pembangunan masjid ini juga terpengaruh oleh kebudayaan Bizantium, karena Masjid Damaskus terdahulu merupakan gereja yang dialihfungsikan menjadi masjid. Pengaruh terhadap bentuk bangunan yang semula memiliki pola sederhana, setelah mendapatkan pengaruh dari kebudayaan luar menambah bentuk dari bangunan dan tidak mengubah bentuk awal dari pola awal. Pada masa pemerintahan Khalifah Abdul Malik dan al-Walid I melakukan perluasaan pada Masjid al-Haram dan Masjid Nabawi (Saputri, 2017, p. 195196).

Penelitian yang telah terjadi hanya mengungkapkan seluk beluk pemerintahan khalifah Abdul Malik bin Marwan. Tetapi, dalam penelitian ini akan mengungkap tentang pemerintahan Arab pada masa khalifah Abdul Malik bin Marwan mengenai hasil dari kebijakan-kebijakannya dalam memajukan dan mengembangkan negeri Arab. Karena sisi dari pembahasan ini belum pernah diungkapkan oleh peneliti sebelumnya. 
Adapun tujuan dari penelitian ini adalah untuk menganalisis Arabisasi pemerintah Islam pada masa Khalifah Abdul Malik bin Marwan. Karena banyak peninggalan-peninggalan sejarah Islam yang telah dikembangkannya dan membuat bangsa dan negara Arab maju dan berkembang pesat. Selanjutnya, Metodologi yang digunakan dalam penelitian ini adalah library research, yaitu suatu penelitian yang dilakukan dengan mengumpulkan data dari informasi yang bersumber berasal dari kepustakaan baik berupa buku, jurnal, artikel dan hasil penelitian lainnya yang sesuai dengan topik kajian yaitu Arabisasi pemerintah Islam pada masa Khalifah Abdul Malik bin Marwan.

\section{METODE DAN FOKUS PENELITIAN}

Penelitian ini merupakan jenis penelitian kepustakaan (library research), dengan menggunakan metode kualitatif dengan pendekatan historis. Sumber data diambil dari kepustakaan baik berupa buku, jurnal, majalah, artikel dan hasil penelitian lainnya yang sesuai dengan topik kajian yaitu Arabisasi Pemerintahan Islam pada masa Khalifah Abdul Malik bin Marwan (Nazir, 2000, p. 54). Yang mana penulis akan menggambarkan dan mengungkapkan kejadian atau fenomena yang telah terjadi pada masa pemerintahan Khalifah Abdul Malik bin Marwan. Kemudian hasil dari penelitian tersebut akan diuraikan untuk mengungkapkan fakta penelitian yang telah diperoleh secara jelas dan sistematis kemudian untuk dianalisa (Syah, 2016, p. 33).

\section{HASIL DAN PEMBAHASAN}

\section{Biografi Abdul Malik bin Marwan}

Abdul Malik lahir pada tahun $23 \mathrm{H}$ pada bulan Ramadhan, nama panjang beliau yaitu Abdul Malik bin Marwan atau Abdul Malik bin Marwan bin Hakam bin Abul Aas bin Umayya bin Abd Shams bi Abdi Manaf bin Qussai bin Kilab. Beliau adalah Khalifah Dinasti Umayyah dan mengganti kedudukan ayahnya yang bernama Marwan bin Hakam (Amin, 1997, p. 28).

Dari segi Pendidikan, Abdul Malik bin Marwan dibesarkan dari keluarga ningrat. Pendidikan, kesejahteraan dan spiritual ia dapatkan dengan mudah. Walaupun demikian sebelum beliau diangkat menjadi khalifah ia tergolong orang yang tidak begitu menyukai kemewahan berupa fasilitas-fasilitas dari ayahnya. Pada zaman mudanya ia termasuk sosok yang zuhud, faqih dan dianggap sebagai salah satu ulama besar di kota Madinah (Arief, 2004, p. 133).

Abdul Malik bin Marwan memulai berkarir yaitu politik. Kekhalifahan ketika ia diangkat sebagai gubernur kota Madinah oleh Muawiyyah. Meskipun saat itu umurnya masih 16 tahun. Ini berarti di samping posisinya sebagai seorang ulama besar dikota Madinah, ia juga merangkap jabatan sebagai seorang politikus pemerintahan yaitu gubernur kota Madinah. Selanjutnya ia menjadi khalifah pusat menggantikan ayahnya, yaitu Marwan bin Hakam. Ayahnya meninggal karena dibunuh oleh ibu tirinya sendiri. Marwan bin Hakam (ayahnya Abdul Malik) menikahi ibunya Khalid yang ia abaikan hak Khalid sebagai pewaris Muawiyyah II, maka ibu Negara (ibunya Khalid) kini istri Marwan bin Hakam tidak menyukainya dan membunuh Marwan dengan mencekik lehernya dalam keadaan tidur (Rachman, 2018, p. 91). 
Abdul Malik bin Marwan dilantik sebagai khalifah disamping setelah ayahnya pada tahun $65 \mathrm{H} / 684 \mathrm{M}$, ada satu yang alasan lain yaitu Abdul Malik bin Marwan berhasil menyingkirkan khalifah yang legal yaitu Abdullah bin Zubair. Abdul Malik bin Marwan berhasil mengambil Irak dari tangan Abdullah bin Zubair dan menaklukan Hijaz secara keseluruhan. Setelah Abdullah bin Zubair terbunuh maka ia dibaiat oleh seluruh masyarakat muslim. Dia menjadi Khalifah sejak tahun 73 H / 692 M. Keadaan negara aman ditangannya (Rachman, 2018, p. 92).

Pada masa awal pemerintahanya, Abdul Malik mengalami banyak hambatan dalam menjalankan pemerintahan. Karena ketika itu bangsa Arab terpecah menjadi beberapa kelompok dengan fanatisme kesukuan masing-masing. Mereka yang tidak puas atas kebijakan Marwan bin al-Hakam, melakukan berbagai gerakan pemberontakan, sehingga wilayah kekuasaan Islam Dinasti Umayyah berada di ujung kehancuran. Pemberontakan pada masa khalifah Abdul Malik bin Marwan, antara lain: (1) Pemberontakan golongan Syi'ah tahun 66 H/586 M; (2) Pemberontakan Abdullah bin Zubair tahun 72H/692 M; (3) Pemberontakan kaum Khawarij; (4). Pemberontakan Amruh ibnu Said tahun 70 H/692 M (Syu'ub, p. 30).

Pada masa awal pemerintahannya, Abdul Malik tidak terlibat langsung didalam pertempuran musuh-musuh yang saling berebut pengaruh. Ia hanya menjadi penonton saja dan menunggu kelemahan mereka diserang. Setelah hancurnya pasukan Khawarij dan pasukan Zubair, Abdul Malik baru mengambil langkah untuk mengatasi kekuatan yang dianggap sudah cukup membahayakan kekuasaannya. Kekuatan-kekuatan yang dianggap telah membahayakan kekuasaannya adalah kekuatan Zubair dan kekuatan yang menentang pemerintahan yang dipimpin oleh Amru bin Sa id di Syiria. Kekuatan Amru ini dapat dilumpuhkan oleh pasukan Abdul Malik. Setelah dilumpuhkannya, Abdul Malik menawarkan ampunan kepadanya. Tawaran itu diterima Amar yang kemudian bergabung dengan Khalifah Abdul Malik. Namun setelah ia bergabung, Amru dihianati dan dibunuh oleh Khalifah Abdul Malik bin Marwan. Ini merupakan taktik licik yang digunakan Khalifah Abdul Malik bin Marwan dalam menyisihkan musuh yang membahayakan kekuasaan Islam (Syu'ub, p. 31).

Abdul Malik bin Marwan wafat pada bulan Syawal tahun 86 Hijriah dalam usia 6o tahun. Ia mewariskan fundamen kekuasaan yang sangat kokoh bagi terbangunnya sebuah dinasti yang disegani dunia. Kelak para sejarawan mengenalnya dengan sebutan Abul Muluk atau ayah para raja. Karena empat putranya, yaitu Al Walid, Sulaiman, Yazid II, dan Hisyam adalah para khalifah Dinasti Umayyah yang membawa dinasti ini mencapai masa keemasannya (Nizar, 2003, p. 60).

\section{Peristiwa-peristiwa penting pada masa Khalifah Abdul Malik bin Marwan}

Peristiwa yang terjadi pada masa khalifah Abdul Malik bin Marwab yaitu pertama, Pemberontakan Abdur rahman ibnul-Asy'ats $(81-85 \mathrm{H} / 700-704 \mathrm{M})$ Hajjaj yang saat itu menjadi Gubernur Irak menguasai Abdur Rahman untuk melakukan penyerangan ke negeri Turki pada tahun $81 \mathrm{H}$. Dan dia berhasil mencapai banyak kemenangan kemenagan. Kemudian dia menyatakan pembangkangannya kepada Hajjaj dan Abdul Malik. Lalu dia memerangi Hajjaj dan berhasil menjadikan Irak di bawah kekuasaannya. Setelah itu wilayah timur berhasil berada di bawah kekuasaannya 
kecuali Khurasan. Di sana terjadi perang antara dia dan pendukung pemerintahan Umayyah. Akhirnya, dia kalah dan melarikan pada tahun $82 \mathrm{H}$ lalu dibunuh pada tahun $85 \mathrm{H} / 704$ M. Hajjaj membunuh sekian banyak ulama yang mengikuti gerakan Abdur Rahman ibnul-Asy'ats ini, di antaranya Said bin Jubair (Yakub, dkk, 2010, p. 69).

Kedua, Hajjaj bin Yusuf ats-Tsaqafi (95 H/714 M) dia adalah orang yang paling terkenal di antara orang dekat Abdul Malik dan sekaligus gubernur yang paling masyhur dalam sejarah. Dia di kenal sebagai seorang yang sangat politis, cerdas, keras dan sekaligus kejam baik saat ia berada dalam keadaan yang hak dan tidak hak. Dia termasuk salah seorang pentolan yang memerangi Mush'ab ibnu Zubair yang kemudian menjadikan Irak berada di bawah kekuasaan Bani Umayyah. Setelah itu dia di perintahkan oleh Abdul Malik untuk memerangi Abdullah ibnu Zubair untuk menaklukan Hijaz. Dia berhasil menaklukannya dan membunuh Abdullah ibnu Zubair. Sejak itulah dia menjadi gubernur Hijaz. Tatkala terjadi krisis di Irak, maka Abdul Malik mengangkatnya sebagai gubernur. Hajjaj menggunakan segala cara kekerasan dan kekejaman untuk melawan orang-orang Irak hingga akhirnya Irak menjadi stabil. Pengaruhnya meliputi semua kawasan timur secara keseluruhan. Dia memiliki peran yang sangat besar dalam melapangkan rintangan yang dihadapi oleh pemerintahan Bani Umayyah. Kekerasannya seakan menjadi suatu kepastian yang harus dia lakukan demi tercapainya keamanan dan kedamaian. Ketiga, gerakan Khawarij mengalami kemajuan di Irak dan Jazirah Arabia. Namun, panglima perang Bani Umayyah berhasil menaklukan mereka dan menghancurkan sebagian besar dari mereka. Pemimpinpemimpin Khawarij yang terkenal di periode ini adalah Qathari ibnul-Fuj'ah dan Syabab ibnusy-Syaibani (Yakub, dkk, 2010, p. 70).

\section{Kebijakan atau Jasa Abdul Malik bin Marwan}

Keberhasilan Abdul Malik bin Marwan mempertahankan keutuhan wilayah kekuasaan dinasti Bani Umayyah, membawa dampak positif bagi kemajuan Dinasti ini. Sebab kendala atau hambatan terpenting didalam usaha mempertahankan dan mengembangkan kekuasaanya, telah dapat diatasi dengan baik. Dengan demikian, mudah baginya untuk mengeluarkan kebijakan politik untuk membangun negeri. Selama masa pemerintahanya, khalifah Abdul Malik bin Marwan melakukan beberapa pembaharuan untuk memperlancar administrasi pemerintahan. Di antara jasa dan pembaharuan yang dilakukan adalah menjadikan bahasa Arab menjadi bahasa resmi Negara (Kholison, 2005, p. 7). Kebijakan ini dikeluarkan karena bahasa yang dipakai untuk kegiatan administrasi pemerintahan didaerah itu pada masa-masa sebelumnya, bukan bahasa arab. Seperti diketahui bahwa pada masa Nabi dan para sahabat dan masa-masa awal dinasti Umayyah seluruh dokumen yang berkaitan dengan perikehidupan dicatat dalam bahasa Arab. Setelah bangsa Persia, Syiria dan Mesir bergabung dalam kekuasaan pemerintahan Islam, Khalifah Umar bin Al-Khatab mempertahankan dokumen yang berkaitan dengan negeri tersebut tetap dicatat dalam bahasa mereka masing-masing. Akibatnya, departemen keuangan negeri-negeri tersebut dikuasai oleh pribumi non muslim yang memahami bahasa mereka (Fadli Mansur, 2003, p. 174).

Ketika Abdul Malik bin Marwan berkuasa, ia menghapuskan bahasa mereka dan menetapkan bahasa Arab sebagai bahasa resmi pemerintahan, kebijakan ini pertama 
kali diterapkan bahasa resmi pemerintahan. Kebijakan ini pertama kali diterapkan di Syiria dan Irak, kemudian Mesir dan Persia. Hal sepadan juga menyebutkan bahwa, ketika bahasa Arab menjadi bahasa percakapan orang-orang non-Arab, bahasa Arab mendapat masukan-masukan kata baru. Kata-kata baru ini diambil dari kata-kata wilayah yang ditaklukkan. Sebagai contoh, kata "kubah" dan "menara". Kedua kata tersebut masuk kedalam kosakata bahasa Arab ketika orang-orang Arab melihat bangunan-bangunan itu. Hal yang lebih menarik lagi bahasa Arab sendiri ternyata memiliki kelenturan menerima kosakata kata baru. Dengan demikian bahasa Arab menjadi sangat kaya dengan kosakata dan istilah. (Permana, 2018, p. 44)

Kedua, mengganti mata uang, Abdul Malik bin Marwan mengganti mata uang. Ia mengeluarkan mata uang logam Arab. Sebelumnya, pada masa Nabi Muhammad SAW dan Khalifah Abu bakar mata uang yang dipakai sebagai alat tukar atau alat bayar adalah mata uang romawi dan persia. Mata uang ini pada masa pemerintahan sesudahnya, khususnya pada masa khalifah Umar bin Khattab telah banyak yang rusak. Inilah salah satu sebab mengapa Abdul Malik bin Marwan melakukan pembaharuan dalam bidang mata uang. Ia mengeluarkan jenis mata uang baru yang bisa dibilang sebagai mata uang resmi pemerintahan islam. Mata uang ini terbuat dari emas (Dinar), perak (Dirham) dan perunggu (Fals atau Fuls), mata uang yang satu sisinya bertuliskan kalimat "Laailaha Illallah" dan sisi lainnya tertulis nama khalifah. Mata uang Islam yang baru ini menghilangkan symbolis Kristen dan Zoroaster. Untuk kepentingan itu, khalifah Abdul malik bin Marwan mendirikan pabrik percetakan uang di Damaskus (Yusuf Al-Isy, 2009, p. 283).

Ketiga, Pembaharuan ragam tulisan bahasa Arab, kebijakan Abdul Malik bin Marwan lainya adalah pembaharuan dalam ragam tulisan bahasa Arab. Hal ini dilakukan karena berdasarkan penilaiannya terdapat dua kelemahan didalam bahasa Arab. Pertama, bahasa arab hanya mengandung huruf konsonan (huruf mati), yang dapat diucapkan dalam beberapa bunyi vokal. Kenyataannya ini menyulitkan bagi masyarakat muslim yang bukan berasal dari bahasa Arab didalam memahami dan mengucapakan bahasa Arab. Kedua, beberapa huruf arab mempunyai kesamaan bentuk, seperti antara huruf ( "da" dan "tha") dan lainya. Hajjaj bin Yusuf salah seorang gubernur Abdul malik yang mahir di dalam seni menulis arab, memperkenalkan tanda vokal dan menerapkan tanda-tanda titik untuk membedakan beberapa huruf yang sama bentuknya. Pembaharuan yang dilakukan khalifah Abdul Malik bin Marwan dan Gubernur Hajjaj bin Yusuf ini menjadikan bahasa Arab lebih sempurna dan sekaligus menghilangkan kesulitan bagi pembaca luas di kalangan non Arab (Al-'Isy, 2009, p. 283).

Keempat, pembaharuan dalam bidang keuangan hingga pada masa pemerintahan Abdul Malik, umat Islam hanya berkewajiban membayar zakat dan bebas dari kharaj dan jizyah. Hal ini mendorong orang non-muslim memeluk agama Islam. Dengan cara ini, mereka terbebas dari pembayaran Kharaj dan jizyah. Setelah itu, mereka meninggalkan tanah pertaniannya guna mencari nafkah di kota-kota besar sebagai tentara. Kenyataan ini menimbulkan masalah bagi perekonomian negara. Karena pada satu sisi perpindahan agama mengakibatkan berkurangnya sumber pendapatan negara dari sektor pajak. Pada sisi lain, bertambahnya militer Islam dari kelompok Mawali memerlukan dana subsidi yang makin besar. Untuk mengatasi 
permasalahan ini, khalifah Abdul Malik mengembalikan beberapa militer Islam kepada profesinya semula, yakni sebagai petani dan menetapkan kepadanya untuk membayar sejumlah kewajiban mereka sebelum mereka masuk Islam, yakni sebesar beban kharraj dan jizyah. Keputusan khalifah Abdul Malik ini tentu saja ditentang keras oleh kelompok Mawali. Karena ketidakpuasan ini, pada akhirnya mereka menyokong gerakan propaganda Abbasiyah untuk menggulingkan dinasti Umayyah (Al-'Isy, 2009, p. 283).

Kelima, pengembangan sistem pos ketika Abdul Malik berkuasa, ia berusaha mengembangkan sistem pos yang telah dibangun pada masa Muawiyah bin Abu Sufyan. Sistem pos ini menghubungkan kota-kota propinsi dengan pemerintahan pusat. Para petugas pos mengendarai kuda dalam menjalankan tugasnya, khususnya tugas menyampaikan informasi penting dari pemerintahan pusat ke pemerintahan propinsi. Selain itu Khalifah juga mendirikan beberapa kota baru, di antara kota terpenting adalah Al-Wasith di antara rendah Irak. Pendirian kota ini dimaksudkan untuk mengendalikan timbulnya gerakan pengacau di wilayah Irak (Al-'Isy, 2007, p. 290).

Keenam, membentuk Mahkamah Agung. Kebijakan lain yang menjadi jasa peniting dari peninggalan pemerintahan khalifah Abdul Mallik adalah mendirikan lembaga Mahkamah Agung. Lembaga ini didirikan untuk mengadili para pejabat tinggi negara yang melakukan penyelewengan atau tindakan yang merugikan bangsa dan Negara atau bertindak sewenang-wenang terhadap rakyat. Ketujuh, mendirikan bangunan-bangunan penting. Keberhasilan lain yang menjadi jasa dari peninggalan Khalifah Abdul Malik adalah menjadikan bangunan-bangunan penting yang sangat dibutuhkan di dalam memperlancar roda pemerintahan dan kekuasaan militer Bani Umayyah. Pada masanya, telah dibangun pabrik-pabrik senjata dan pabrik kapal perang di Tunisia. Membangun Kubah baru (Qubbah Al-Sakhra) di Yerussalem. Yang hingga kini masih terpelihara dengan baik dan masih utuh (Al-'Isy, 2007, p. 290).

Kedelapan, kerajinan-kerajinan atau seni. Pada masa Abdul Malik mulai dirintis pembuatan tiraz atau semacam bordiran yakni cap resmi yang dicetak pada pakaian khalifah dan para pembesar pemerintahan. Kesembilan, membangun sarana dan prasarana. Abdul Malik juga mendirikan bangunan seperti pabrik senjata dan kapal perang di Tunisia. Ia juga membangun Masjid Umar atau Qubbatush Shakra' di Yerusalem dan memperluas Masjidil Haram di Makkah (Al-'Isy, 2007, p. 290)

Jasa-jasa lain kepemimpinan Abdul Malik bin Marwan: (1) Mempertahankan keberlangsungan Dinasti Umayyah; (2). Menciptakan kesejahteraan rakyat melalui perbaikan administrasi Negara; (3) Menyempurnakan mushaf Al-Qur'an (3) Menguasai wilayah-wilayah yang berada dalam cengkraman non muslim (4) Menata administrasi Negara dalam rangka mengumpulkan dan meneliti dokumen-dokumen penting milik Negara; (5) Menunjuk orang-orang yang berkompeten untuk menduduki jabatan gubernur dan penguasa di daerah-daerah yang dianggap penting; (6) Meredam gangguan dan ancaman dari kelompok orang-orang yang mendorong kewibawaan Negara (Sunanto, 2003, p. 43).

\section{Akhir Pemerintahan Abdul Malik bin Marwan}


Abdul Malik memerintah selama kira-kira dua belas tahun, masa-masa makmur dan tentram. Keseluruhan kerajaan timur dipimpin oleh al-Hajjaj, penakluk Mekkah yang bertangan besi, sementara jabatan-jabatan propinsi diberikan pada keluargakeluarga khalifah. Ini berarti pemusatan kekuasaan di tangan Abdul Malik. Penguasaannya atas rincian-rincian administrasi diperkuat oleh perintahnya untuk memakai bahasa Arab di seluruh negara. Ketika orang-orang Arab mula-mula menaklukan berbagai propinsi, mereka mempertahankan pejabat-pejabat propinsi dan lokal yang sudah ada dan mengizinkan mereka terus memakai bahasa Yunani, Syria atau bahasa apapun yang telah dipakai. Ini sekarang diubah tetapi, pejabat-pejabat yang sama terus boleh menjabat dan tidak diharuskan masuk Islam. Namun lama kelamaan, makin banyak Muslimin yang terampil dalam pekerjaan kantor dan mereka yang tidak beragama Islam masuk Islam atau digeser (Sunanto, 2003, p. 44).

Abdul Malik dan al-Hajjaj juga memperkenalakan mata uang yang asli Arab. Dalam keberhasilan penaklukan pertama, orang-orang Arab tidak sempat memikirkan untuk mencetak mata uang dan sudah puas memakai mata uang yang sudah beredar di Arabia dan negeri-negeri taklukan,kebanyakan adalah mata uang Bizantium dan Persia. Belakangan beberapa ayat Al-Qur'an ditumpangkan pada kedua mata uang tersebut, tetapi Abdul Malik adalah khalifah pertama yang mencetak mata uang dengan mencantumkan kalimat-kalimat Arab dan Islam saja. Mata uang dibuat dari dua jenis logam yaitu dinar emas dan dirham perak. Nilai tukar ditetapkan sepuluh atau dua belas dirham buat satu dinar, tetapi nilai sebenarnya tergantung pada fluktuasi pasar dan berada di berbagai saat dan tempat, dimana nilai dirham sangat berkurang. Orangorang Arab juga mengambil alih system perpajakan yang sudah berlaku, terutanma pajak tanah dan pajak kepala, tetapi pada saat yang sama mulai mengadakan perubahan dalam perpajakan supaya lebih sesuai dengan ajaran Islam (Sunanto, 2003, p. 45).

\section{PENUTUP}

Peradaban Islam pada masa Khalifah Abdul Malik bin Marwan, sangatlah berkembang dengan pesat, diantaranya: Pertama, Abdul Malik bin Marwan meresmikan bahasa Arab sebagai bahasa resmi negara setempat, karena pada masanya harus menggunakan bahasa Arab. Kedua, membuat uang logam dari emas, Abdul Malik mengganti uang logam dari sejak Rasulullah, kemudian ia mengganti dengan dinar atau emas. Ketiga, membuat kantor pos agar lancar komunikasi antar negara dengan negara lainnya. Keempat, mendirikan Mahkamah Agung. Kelima, mendirikan bangunan untuk pertemuan para pejabat dalam pertemuan. Keenam, membuat kerajinan tangan seperti, melukis dan menjahit. Itu semua adalah kerja keras dari Abdul Malik bin Marwan agar negara pada waktu itu maju, berkembang dan disegani oleh negara dan bangsa lain.

\section{REFERENSI}

Al-'Isy, Yusuf. (2007). Sejarah Dinasti Umayyah. Jakarta: Pustaka Al-Kautsar.

Al-'Isy, Yusuf. (2009). Dinasti Umawiyah. Jakarta: Pustaka Al-Kautsar.

Amin, Husyn Ahmad. (1997). Seratus Tokoh dalam Sejarah Islam. Bandung: Remaja Rosdakarta Offset. 
Arief, Armai. (2004). Sejarah Pertumbuhan dan Perkembangan Lembaga-lembaga Pendidikan Pendidikan Islam Klasik. Bandung: Angkasa.

Kholison, M. (2015). Bahasa Arab: Sejarah dan Perkembangannya. Jurnal Sejarah dan Perkembangan, 7(1). Retrieved from http://ejournal.iainjember.ac.id/index.php/turats/article/view/76.

Kuswanjono, Arqom. (2016). Hakikat Ilmu dalam Pemikiran Islam. Jurnal Filsafat, 26(2). Retrieved from https://jurnal.ugm.ac.id/wisdom/article/view/12787/9152.

Mansur, Fadli Munawwar. (2003). Pertumbuhan dan Perkembangan Budaya Arab pada Masa Bani Umayyah. Jurnal Humaniora, 15(2). DOI: https://doi.org/10.22146/jh.785.

Nazir, M. (1988). Metode Penelitian. Jakarta: Ghalia Indonesia.

Nizar, Samsul. (2013). Sejarah Pendidikan Islam (Menelusuri Jejak Sejarah Pendidikan Era Rasulullah sampai Indonesia). Jakarta: Kencana Prenada Media Group.

Permana, Farid. (2018). Pendidikan Islam dan Pengajaran Bahasa Arab pada Masa Dinasti Umayyah, Jurnal Ilmiah Al-Qalam, 12(2). Retrieved from https://jurnal.stiq-amuntai.ac.id/index.php/al-qalam/article/download/74/64

Rachman, Taufik. (2018). Bani Umayyah di lihat dari tiga Fase (Fase terbentuk, Kejayaan dan Kemunduran). Jurnal Sejarah Peradaban Islam, 2(1). Retrieved from http://jurnal.uinsu.ac.id/index.php/juspi/article/download/1079/1428.

Rianawati. 2010. Sejarah dan Peradaban Islam. Pontianak: STAIN Pontianak Press.

Saputri, Itsnawati Nurrohman. (2017). Perkembangan Kubah Batu, Masjid Damaskus, Perluasan Masjid Al-Haram dan Masjid Nabawi pada Masa Khalifah Abdul Malik bin Marwan dan Walid bin Abdul Malik. Jurnal Millati, 2(2). Retrieved from

http://millati.iainsalatiga.ac.id/index.php/millati/article/download/1256/796.

Sunanto, Musyrifah. (2003). Sejarah Islam Klasik. Bogor: Kencana.

Syah, Hidayah. (2016). Metodologi Penelitian Kuantitatif dan Kualitatif. Pekanbaru: Indrasakti Riau.

Syu'ub, Muhammad. (Tanpa Tahun). Sejarah Bani Umayyah. Jakarta: PT.Bulan Bintang.

Yakub, dkk. 20o8. Sejarah Peradaban Islam. Medan: Perdana Publishing. 